\title{
Glucagon-like peptide 1 receptor plays a critical role in geniposide-regulated insulin secretion in INS-1 cells
}

\author{
Li-xia GUO ${ }^{1,2}$, Zhi-ning XIA ${ }^{1, *}$, Xue GAO², Fei YIN², Jian-hui LIU², * \\ ${ }^{1}$ College of Bioengineering, Chongqing University, Chongqing 400030, China; ${ }^{2}$ Research Centre of Medicinal Chemistry and Chemical \\ Biology, Chongqing Technology and Business University, Chongqing 400067, China
}

\begin{abstract}
Aim: To explore the role of the glucagon-like peptide 1 receptor (GLP-1R) in geniposide regulated insulin secretion in rat INS-1 insulinoma cells.

Methods: Rat INS-1 insulinoma cells were cultured. The content of insulin in the culture medium was measured with ELISA assay. GLP-1R gene in INS-1 cells was knocked down with shRNA interference. The level of GLP-1R protein in INS-1 cells was measured with Western blotting.

Results: Geniposide (0.01-100 $\mu \mathrm{mol} / \mathrm{L})$ increased insulin secretion from INS-1 cells in a concentration-dependent manner. Geniposide $(10 \mu \mathrm{mol} / \mathrm{L})$ enhanced acute insulin secretion in response to both the low $(5.5 \mathrm{mmol} / \mathrm{L})$ and moderately high levels $(11 \mathrm{mmol} / \mathrm{L})$ of glucose. Blockade of GLP-1R with the GLP-1R antagonist exendin (9-39) (200 nmol/L) or knock-down of GLP-1R with shRNA interference in INS-1 cells decreased the effect of geniposide $(10 \mu \mathrm{mol} / \mathrm{L})$ on insulin secretion stimulated by glucose $(5.5 \mathrm{mmol} / \mathrm{L})$. Conclusion: Geniposide increases insulin secretion through glucagon-like peptide 1 receptors in rat INS-1 insulinoma cells.
\end{abstract}

Keywords: geniposide; glucagon-like peptide 1 receptor; insulin secretion; type 2 diabetes mellitus; RNA interference

Acta Pharmacologica Sinica (2012) 33: 237-241; doi: 10.1038/aps.2011.146; published online 21 Nov 2011

\section{Introduction}

Type 2 diabetes mellitus involves defects in both insulin secretion and insulin sensitivity. Multiple insulin secretion defects could occur, including the absence of pulsatility ${ }^{[1]}$, loss of the early phase of insulin secretion after glucose stimulation ${ }^{[2]}$, decreased basal and stimulated concentrations of insulin in the plasma ${ }^{[3]}$, excess secretion of pro-hormone, and progressive decreases in insulin secretory capacity ${ }^{[4]}$. Thus, the regulation of insulin secretion in pancreatic $\beta$ cells has long been considered important for the prevention and treatment of type 2 diabetes mellitus ${ }^{[4]}$.

Emerging data have shown that GLP-1 functions through its receptor to regulate insulin secretion and glucose metabolism and is, therefore, a potentially important target in the treatment of type 2 diabetes. GLP- 1 is able to improve insulin secretion in subjects with impaired glucose tolerance and type 2 diabetes $^{[5]}$. Studies have demonstrated that increased

\footnotetext{
* To whom correspondence should be addressed.

E-mail znxia@cqu.edu.cn (Zhi-ning XIA); jhliu@ctbu.edu.cn (Jian-hui LIU)

Received 2011-05-25 Accepted 2011-09-30
}

expression or activity of GLP-1R is beneficial to $\beta$ cell functions, including insulin synthesis/secretion ${ }^{[6]}$, proliferation $^{[7]}$, neogenesis ${ }^{[7]}$, and anti-apoptosis ${ }^{[8]}$. Unfortunately, GLP-1 has a half-life of less than 2 minutes in the circulatory system owing to rapid degradation by dipeptidyl peptidase-4 (DPP IV) ${ }^{[9]}$.

Utilizing a high-throughput screening assay, we previously identified geniposide as a potent agonist of GLP-1R and possessed neurotrophic and neuroprotective properties ${ }^{[10-12]}$. However, it is unknown whether geniposide is able to improve insulin secretion in pancreatic $\beta$ cells. In the present study we examined the effect of geniposide on insulin secretion in INS-1 cells. The results demonstrate that geniposide increased insulin secretion in a dose-dependent manner and enhanced glucose-stimulated insulin secretion in INS-1 cells. We have further observed that exendin (9-39), an antagonist of GLP-1R, and GLP-1R siRNA decreased the effect of geniposide on glucose-stimulated insulin secretion in INS-1 cells.

\section{Materials and methods}

Cell culture

An INS-1 rat insulinoma cell line was purchased from the CCTCC (China Center for Type Culture Collection). The cells 
were grown in a humidified atmosphere with $5 \% \mathrm{CO}_{2}$ at $37^{\circ} \mathrm{C}$. The culture medium was RPMI-1640 containing $11 \mathrm{mmol} / \mathrm{L}$ glucose, which was supplemented with $10 \%$ FBS, $10 \mathrm{mmol} / \mathrm{L}$ HEPES, $100 \mathrm{U} / \mathrm{mL}$ penicillin, $100 \mu \mathrm{g} / \mathrm{mL}$ streptomycin, 2 $\mathrm{mmol} / \mathrm{L}$ L-glutamine, $1 \mathrm{mmol} / \mathrm{L}$ sodium pyruvate, and 50 $\mu \mathrm{mol} / \mathrm{L}$ mercaptoethanol. Cells were passaged every week following trypsinization.

\section{Geniposide induces insulin secretion in a concentration-depend-} ent manner

To investigate the effect of geniposide on insulin secretion, INS-1 cells were seeded onto 12-well plates and cultured for $24 \mathrm{~h}$. The cells were washed twice with Krebs-Ringer bicarbonate buffer (KRBH; $129 \mathrm{mmol} / \mathrm{L} \mathrm{NaCl}, 4.8 \mathrm{mmol} / \mathrm{L} \mathrm{KCl}, 1.2$ $\mathrm{mmol} / \mathrm{L} \mathrm{MgSO}_{4}, 1.2 \mathrm{mmol} / \mathrm{L} \mathrm{KH}_{2} \mathrm{PO}_{4}, 2.5 \mathrm{mmol} / \mathrm{L} \mathrm{CaCl}_{2}, 5$ $\mathrm{mmol} / \mathrm{L} \mathrm{NaHCO}_{3}, 0.1 \%$ BSA, $10 \mathrm{mmol} / \mathrm{L} \mathrm{HEPES}$; $\mathrm{pH} 7.4$ ) and starved for $2 \mathrm{~h}$ in KRBH buffer. Then, the cells were incubated with fresh $\mathrm{KRBH}$ containing different concentrations of geniposide $(0,0.01,0.1,1.0,10$, or $100 \mu \mathrm{mol} / \mathrm{L})$ for $1 \mathrm{~h}$. The supernatants were collected to determine the insulin content using commercial kit (Linco Research, Inc, Missouri, USA) according to the kit' instructions.

\section{Effect of geniposide on insulin secretion stimulated by glucose}

To explore the influence of geniposide on glucose-stimulated insulin secretion, INS-1 cells were seeded onto 12-well plates and cultured for $24 \mathrm{~h}$. After the cells were washed two times with fresh $\mathrm{KRBH}$ and starved for $2 \mathrm{~h}$ in fresh $\mathrm{KRBH}$, the cells were incubated with $10 \mu \mathrm{mol} / \mathrm{L}$ geniposide in the absence or presence of indicated concentrations of glucose for $1 \mathrm{~h}$. The supernatants were collected and analyzed for insulin concentration using commercial kit (Linco Research, Inc, Missouri, USA) according to the kit' instructions.

\section{The role of GLP-1R in geniposide-inducing insulin secretion}

To probe the role of GLP-1R, we investigated the effect of an antagonist for GLP-1R on insulin secretion in the presence of a low concentration of glucose. INS-1 cells were starved for $2 \mathrm{~h}$ in fresh $\mathrm{KRBH}$, placed for $1 \mathrm{~h}$ in fresh $\mathrm{KRBH}$ containing $200 \mathrm{nmol} / \mathrm{L}$ exendin (9-39), and then treated for $1 \mathrm{~h}$ with $5.5 \mathrm{mmol} / \mathrm{L}$ glucose in the presence or absence of $10 \mu \mathrm{mol} / \mathrm{L}$ geniposide. The supernatants were collected to probe the insulin concentration using commercial kits.

To further explore the role of GLP-1R in the regulatory effects of geniposide on insulin secretion, we constructed a stable INS-1 cell line with the GLP-1R silenced by a shGLP-1R plasmid, which was optimized in our previous work ${ }^{[11]}$. The level of GLP-1R expression was analyzed with Western blot and real-time PCR. The primers were 5'-TATTGGCTCATCATACGCTTG-3' (GLP-1R sense), 5'-GTCTGCATTTG ATGTCGGTCT-3' (GLP-1R antisense), 5'-AAGTTCAACGGCACAGTCAAG-3' (GAPDH sense) and 5'-CCAGTAGACTCCACGACATACTCA-3' (GAPDH antisense). The mRNA and protein levels of GLP-1R are about 35.4\% and 21\% those of the control, respectively. Using the same protocol as introduced in Materials and Methods, we determined the insulin secretion induced by geniposide in INS-1 cells in which GLP-1R had been knocked down.

\section{Statistical analysis}

Data are expressed as the means \pm SD from at least three independent experiments. When significance was detected, the differences between the treatments were analyzed using a one-way ANOVA with the Origin 8.0 Pair-Sample t-Test. The significance level was set at $P<0.05$.

\section{Results}

\section{Geniposide regulates insulin secretion in INS-1 cells}

As shown in Figure 1, geniposide elicited concentrationdependent increases in insulin secretion in $\beta$ cells. Similar to GLP-1, geniposide also increased acute insulin secretion in response to both low and moderately high glucose levels (Figure 2).

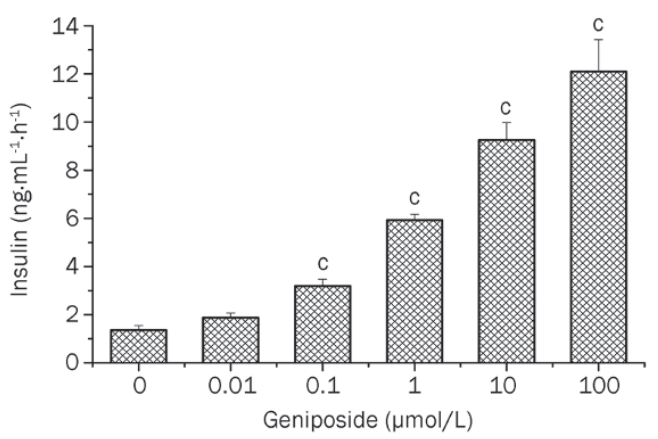

Figure 1. Geniposide induces insulin secretion in a concentrationdependent manner in INS-1 cells. The INS-1 cells at passages of 68-73 were seeded at $5 \times 10^{5}$ cells/well in 12-well-plates. The next day, the cells were washed twice with KRBH buffer and starved in KRBH buffer for $2 \mathrm{~h}$. The media was changed with fresh KRBH containing different concentrations of geniposide $(0,0.01,0.1,1.0,10$, or $100 \mu \mathrm{mol} / \mathrm{L})$. Following 1-h incubation, the medium was collected and analyzed for insulin concentration. Data are expressed as means \pm SD from 4 independent experiments. ${ }^{\circ} P<0.01$ vs control by one-way ANOVA followed by the Pair-Sample $t$-Test using Origin 8.0 software.

In normoglycemic subjects, glucose-stimulated insulin secretion is characterized by a biphasic pattern, with the peak of the first phase rising abruptly 3-5 min after glucose stimulation and lasting for about $10 \mathrm{~min}^{[4]}$. To determine whether geniposide induces changes in both phases of insulin secretion, we tested the influence of geniposide on biphasic insulin secretion in INS-1 cells in the absence or presence of low glucose levels. It was observed that geniposide enhanced insulin secretion in both phases when glucose was present (Figure 3).

GLP-1R plays an important role in geniposide-induced insulin secretion in INS-1 cells.

Our previous work showed that geniposide was an agonist of GLP-1R $\mathrm{R}^{[10-12]}$. To investigate the role of GLP-1R in glucosestimulated insulin secretion, we determined the effect of 


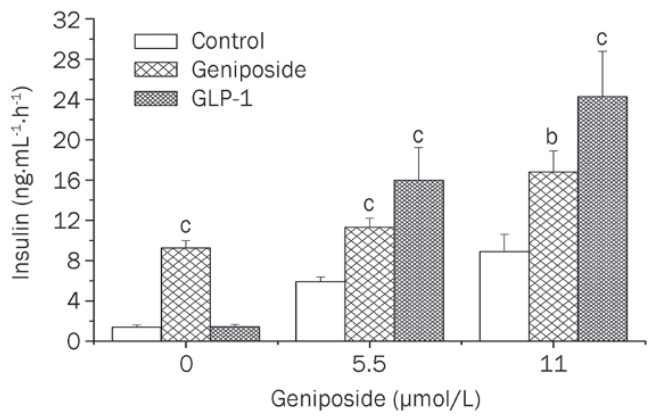

Figure 2. Geniposide potentiates glucose-stimulated insulin secretion in INS-1 cells. INS-1 cells were seeded in 12-well-plates and continued to incubate for $24 \mathrm{~h}$; the cells were washed twice with fresh KRBH and starved in KRBH buffer for $2 \mathrm{~h}$. The media was changed with fresh KRBH containing different concentrations of glucose $(0,5.5$, or $11 \mathrm{mmol} / \mathrm{L})$ with or without $10 \mu \mathrm{mol} / \mathrm{L}$ geniposide or GLP-1 (330 nmol/L). Following 1-h incubation, the medium was collected and analyzed for insulin concentration. Data are expressed as means $\pm S D$ from 6 independent experiments. ${ }^{b} P<0.05,{ }^{c} P<0.01$ vs control at the same glucose concentration by one-way ANOVA followed by the Pair-Sample $t$-Test using Origin 8.0 software.

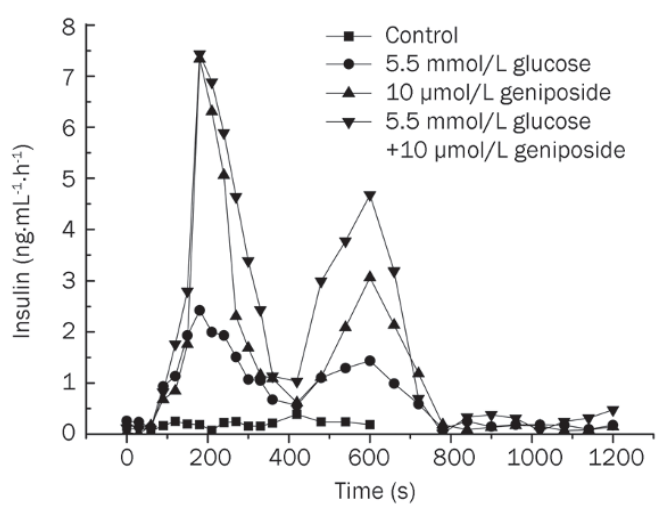

Figure 3. Effects of geniposide on the biphasic glucose-stimulated insulin secretion in INS-1 cells. INS-1 cells were treated with $10 \mu \mathrm{mol} / \mathrm{L}$ geniposide in the presence or absence of $5.5 \mathrm{mmol} / \mathrm{L}$ glucose (G5.5) for $20 \mathrm{~min}$. The media were collected in a 30-s intermediate to determine the insulin secretion with ELISA. Data are expressed as mean of two independent experiments.

geniposide on insulin secretion in the presence or absence of a GLP-1R antagonist, exendin (9-39) amide. The data demonstrate that pretreatment with $200 \mathrm{nmol} / \mathrm{L}$ exendin (9-39) for $1 \mathrm{~h}$ prevented the geniposide-induced increase in insulin secretion in INS-1 cells (Figure 4A).

We also checked the effect of GLP-1R interference on geniposide-induced insulin secretion in INS-1 cells. The results showed that, in INS-1 cells in which GLP-1R had been knocked down, the level of insulin secretion induced by 5.5 $\mathrm{mmol} / \mathrm{L}$ glucose did not differ from that of the control cells. These results suggest that glucose-stimulated insulin secretion is not dependent upon GLP-1R. However, in contrast to normal cultured INS-1 cells, geniposide failed to enhance glucose
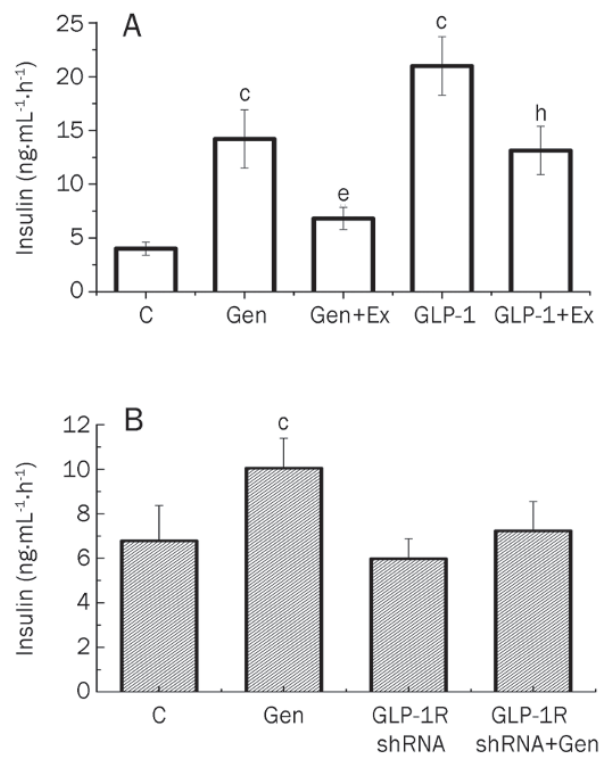

Figure 4. GLP-1R plays a critical role in geniposide-induced insulin secretion in INS-1 cells. (A) After the attached INS-1 cells were washed twice and starved for $2 \mathrm{~h}$, the media was changed with KRBH buffer containing $5.5 \mathrm{mmol} / \mathrm{L}$ glucose, and INS-1 cells were treated with geniposide $(10 \mu \mathrm{mol} / \mathrm{L})$ or GLP-1 $(330 \mathrm{nmol} / \mathrm{L})$ in the presence or absence of GLP-1 receptor antagonist, exendin (9-39) (Ex, $200 \mathrm{nmol} / \mathrm{L}$ ) for $1 \mathrm{~h}$. (B) GLP-1R-interferred INS-1 cells and control cells were treated with $5.5 \mathrm{mmol} / \mathrm{L}$ glucose for $1 \mathrm{~h}$ in the presence or absence of 10 $\mu \mathrm{mol} / \mathrm{L}$ geniposide, respectively. The media were collected to determine the level of insulin secretion. Data are expressed as means \pm SD from 6 independent experiments. ${ }^{c} P<0.01$ vs control. ${ }^{e} P<0.05$ vs geniposide group; ${ }^{\mathrm{h}} P<0.05$ vs GLP-1 group by one-way ANOVA followed by the PairSample $t$-Test using Origin 8.0 software.

stimulated insulin secretion in GLP-1R- knockdown INS-1 cells (Figure 4B). Taken together with the effect of exendin (9-39) on geniposide regulation of glucose-stimulated insulin secretion, these results indicate that GLP-1R plays an important role in geniposide regulation of insulin secretion in INS-1 cells.

\section{Discussion}

Type 2 diabetes mellitus is a metabolic disorder that manifests mainly as abnormalities in pancreatic insulin secretion and the peripheral actions of insulin. During the progression of diabetes, the mass of $\beta$ cells is reduced, with a concomitant decrease in the amount of insulin secreted. An effective therapeutic option is to use drugs to boost the production and release of insulin by pancreatic islets. For example, sulfonylurea-based drugs that act on the $\beta$-cell secretory apparatus augment the release of insulin, overcoming peripheral insulin resistance and restoring normoglycemia in type 2 diabetic patients. Nonetheless, treatment with sulfonylureas is associated with side-effects, such as non-optimal normoglycemic control, which triggers protracted hypoglycemic episodes, worsens myocardial function, and potentially causes weight gain ${ }^{[13,14]}$.

Alternatively, natural hypoglycemic compounds may offer 
advantages over the drugs currently used for diabetes. For example, plant-derived iridoids, of which many are dietary constituents, may serve as promising candidates for the development of therapeutics to prevent or treat diabetes. Jin et al reported that aucubin lowers blood glucose and protects the pancreas from oxidative stress in streptozotocin-induced diabetes. Thus, aucubin might have potential as a safe preventive agent against diabetes ${ }^{[15]}$. In the present study, we examined the effect of geniposide, one of the main iridoid glucoside of Gardenia fruit, on insulin secretion and GLP-1R. We found, for the first time, that geniposide induces insulin secretion in $\beta$-cells in a dose-dependent manner and that geniposide has a synergistic effect on insulin secretion in INS-1 cells in the presence of low and moderately high doses of glucose. We also observed that geniposide directly induced insulin secretion in INS-1 cells in the absence of glucose. These results may be a consequence of the activation of GLP-1R by geniposide, which regulates the concentration of $\mathrm{Ca}^{2+}$ through a signal pathway, or changes in the energy balance of INS-1 cells, which alters the ATP ratio and further regulates the activity of ATP-sensitive $\mathrm{K}^{+}$channels.

GLP-1 is an incretin, which is released in response to carbohydrate and fat intake and enhances glucose-stimulated insulin secretion ${ }^{[16]}$. An increasing number of studies have demonstrated the benefits of GLP-1 for increasing pancreatic $\beta$ cell mass and function. Because GLP-1 exerts its beneficial effects through binding and activating its receptor, GLP-1R is a valuable target for the treatment of diabetes ${ }^{[17]}$. However, GLP-1 has an extremely short half-life owing to rapid degradation by DPP IV, which limits the therapeutic value of exogenous GLP-1 ${ }^{[9]}$. Therefore, it is important to develop small molecules that are able to activate GLP-1R. The ability of geniposide to activate GLP-1R has previously been demonstrated in neurons ${ }^{[10,12]}$. However, the effects of this compound on the regulation of insulin secretion and GLP-1R are poorly understood. It is conceivable that GLP-1R agonists can play a role as anti-diabetic agents and as tools for researching islet metabolism. Nevertheless, our findings about the action of geniposide on $\beta$-cell insulin secretion warrant investigation into the molecular mechanisms involved. Moreover, we also observed that both exendin (9-39) and GLP-1R siRNA off-set the effect of geniposide on insulin secretion, suggesting that GLP-1R plays a critical role in the geniposide-induced increase in insulin secretion by INS-1 cells.

Additionally, the observed increase in glucose-stimulated insulin secretion in INS-1 cells following incubation with geniposide was especially evident during the first-phase of insulin secretion. In type 2 diabetes mellitus, the first-phase of insulin secretion is abolished and late phase secretion is reduced and delayed ${ }^{[18]}$. The early phase of insulin secretion is pivotal in the transition from the fasting state to the fed state with a different function ${ }^{[19]}$. A reduction in the firstphase of insulin secretion has been found both in patients with overt type 2 diabetes mellitus and at the early stage of disease development, which involves impaired glucose tolerance and a slightly elevated fasting glucose ${ }^{[20]}$. The effect of geniposide on insulin secretion through activation of GLP-1R suggests that geniposide may be a potential therapeutic agent for the prevention or treatment of type 2 diabetes.

\section{Acknowledgements}

This work was supported by grants from the National Natural Science Foundation of China (30973576), the Key Project of the Chinese Ministry of Education (209098), the Chongqing Science \& Technology committee (CSTC, 2009BA5069, 2009BB5373, 2011jjA1396), the Chongqing Municipal Education Committee (KJ090710; KJ090733) and the Innovative Research Team Development Program at the University of Chongqing (No KJTD201020). The authors are grateful to Prof Yan-wen WANG from the Institute for Nutrisciences and Health, and the National Research Council of Canada for providing suggestions and corrections during the preparation of this manuscript.

\section{Author contribution}

Jian-hui LIU and Zhi-ning XIA designed the research; Li-xia GUO, Zhi-ning XIA, Xue GAO, Fei YIN, and Jian-hui LIU performed the research; and Jian-hui LIU and Li-xia GUO analyzed the data and wrote the paper.

\section{References}

1 Bergsten P. Pathophysiology of impaired pulsatile insulin release. Diabetes Metab Res Rev 2000; 16: 179-91.

2 Kano Y, Kanatsuna T, Nakamura N, Kitagawa Y, Mori H, Kajiyama S, et al. Defect of the first-phase insulin secretion to glucose stimulation in the perfused pancreas of the nonobese diabetic (NOD) mouse. Diabetes 1986; 35: 486-90.

3 Hartter E, Svoboda T, Ludvik B, Schuller M, Lell B, Kuenburg E, et al. Basal and stimulated plasma levels of pancreatic amylin indicate its co-secretion with insulin in humans. Diabetologia 1991; 34: 52-4.

4 Guillausseau PJ, Meas T, Virally M, Laloi-Michelin M, Medeau V, Kevorkian JP. Abnormalities in insulin secretion in type 2 diabetes mellitus. Diabetes Metab 2008; 34 Suppl 2: S43-8.

5 Arulmozhi DK, Portha B. GLP-1 based therapy for type 2 diabetes. Eur J Pharm Sci 2006; 28: 96-108.

6 Kielgast U, Holst J, Madsbad S. Treatment of type 1 diabetic patients with glucagon-like peptide-1 (GLP-1) and GLP-1R agonists. Curr Diabetes Rev 2009; 5: 266-75.

7 Egan JM, Bulotta A, Hui H, Perfetti R. GLP-1 receptor agonists are growth and differentiation factors for pancreatic islet beta cells. Diabetes Metab Res Rev 2003; 19: 115-23.

8 Cornu M, Thorens B. GLP-1 protects beta-cells against apoptosis by enhancing the activity of an IGF-2/IGF1-receptor autocrine loop. Islets 2009; 1: 280-2.

9 Ahren B, Winzell MS, Wierup N, Sundler F, Burkey B, Hughes TE. DPP4 inhibition improves glucose tolerance and increases insulin and GLP-1 responses to gastric glucose in association with normalized islet topography in mice with beta-cell-specific overexpression of human islet amyloid polypeptide. Regul Pept 2007; 143: 97-103.

10 Liu JH, Zheng XX, Yin F, Hu YH, Guo LX, Deng X, et al. Neurotrophic property of geniposide for inducing the neuronal differentiation of PC12 cells. Int J Dev Neurosci 2006; 24: 419-24.

11 Yin F, Liu JH, Zheng XX, Guo LX. GLP-1 receptor plays a critical role in geniposide-induced expression of heme oxygenase-1 in PC12 cells. Acta Pharmacol Sin 2010; 31: 540-5. 
12 Liu JH, Yin F, Zheng XX, Jing JJ, Hu YH. Geniposide, a novel agonist for GLP-1 receptor, prevents PC12 cells from oxidative damage via MAP kinase pathway. Neurochem Int 2007; 51: 361-9.

13 Martin S, Kolb H, Beuth J, van Leendert R, Schneider B, Scherbaum WA. Change in patients' body weight after 12 months of treatment with glimepiride or glibenclamide in type 2 diabetes: a multicentre retrospective cohort study. Diabetologia 2003; 46: 1611-7.

14 Jennings AM, Wilson RM, Ward JD. Symptomatic hypoglycemia in NIDDM patients treated with oral hypoglycemic agents. Diabetes Care 1989; 12: 203-8.

15 Jin L, Xue HY, Jin $\sqcup$, Li SY, Xu YP. Antioxidant and pancreas-protective effect of aucubin on rats with streptozotocin-induced diabetes. Eur J Pharmacol 2008; 582: 162-7.

16 Marguet D, Baggio L, Kobayashi T, Bernard AM, Pierres M, Nielsen PF, et al. Enhanced insulin secretion and improved glucose tolerance in mice lacking CD26. Proc Natl Acad Sci U S A 2000; 97: 6874-9.

17 Verspohl EJ. Novel therapeutics for type 2 diabetes: incretin hormone mimetics (glucagon-like peptide-1 receptor agonists) and dipeptidyl peptidase-4 inhibitors. Pharmacol Ther 2009; 124: 113-38.

18 Davies MJ, Rayman G, Grenfell A, Gray IP, Day JL, Hales CN. Loss of the first phase insulin response to intravenous glucose in subjects with persistent impaired glucose tolerance. Diabet Med 1994; 11: 432-6.

19 Del Prato S, Marchetti P, Bonadonna RC. Phasic insulin release and metabolic regulation in type 2 diabetes. Diabetes 2002; 51: S10916.

20 Widen El, Eriksson JG, Ekstrand AV, Groop LC. The relationship between first-phase insulin secretion and glucose metabolism. Acta Endocrinol (Copenh) 1992; 127: 289-93. 